\title{
The Effects of Cognitive-Behavioral Counseling on Self-esteem and Tendency of Mobile Phone Addiction
}

\author{
Belardo Farjantoky ${ }^{1}$, Sunawan Sunawan, Mulawarman Mulawarman \\ Universitas Muhammadiyah Metro, Indonesia ${ }^{1}$ \\ Universitas Negeri Semarang, Indonesia \\ @belardoexpresso@gmail.com ${ }^{1}$
}

\section{Article Information:}

Received November 25, 2019

Revised November 27, 2019

Accepted November 28, 2019

Keywords: cognitive-behavioral counseling; mobile phone addiction tendencies; selfesteem

\begin{abstract}
The mobile phone users in students are increased dramatically. Unfortunately, excessive use of mobile phone could cause addiction. The addiction to mobile phone affecting the personal and social life of students. Therefore, authors decided to identify the effect of cognitivebehavioral counseling interventions on self-esteem and the tendency of mobile phone addiction in students of Vocational School 1 Muhammadiyah Semarang. Participants in the pretest were 120 students. This study used a quasi-experiment method, pretest-posttest control group design involving 12 students, randomly divided to experiment ( 6 students) and control group (6 students). The samples were selected using purposive sampling with low self-esteem criteria and a high tendency for mobile phone addiction. The MANCOVA test results proved that cognitive-behavioral counseling had an effect on self-esteem (F1.8 $=265.28 ; \eta p 2=0.963$; $p<0.001$ ), and the tendency of mobile phone addiction ( $F 1.8=1115.90$; $\eta p 2=0.973 ; p<0.001)$. The findings of this study proved that there were effects of cognitive-behavioral counseling interventions on self-esteem and the tendency of mobile phone addiction.
\end{abstract}

\section{INTRODUCTION}

Lately, mobile phone users have increased dramatically, it can be seen that active internet users, especially in mobile phones, reach 171.17 (54.68\%) million of the 264.16 million population (Indonesia, 2018). This situation has penetrated all age groups, especially among adolescents or millennials in Indonesia, around the age of 15-19 years reaching 91\% (Heriyanto, 2018). A large amount of time allocated on a mobile phone has the potential to cause a tendency for mobile phone addiction (Chen et al., 2016; Sapacz, Rockman, \& Clark, 2016).

Seen in three-quarter more than half (57\%) respondents on average often check their cell phones at least once every five minutes without any warning or notification coming from a mobile phone, then a third (36\%) have difficulty concentrating as a result of using a mobile phone (Emanuel et al., 2015). In addition, there are 207 students in high school, where 121 people (58.8\%) experienced unfavorable categories of mobile phone use, because students use to spend more than 3 hours/day using social media more frequently, playing games, as well as with the aim of finding information, resulting in problems with interaction with family, social environment and academics, even in the contemplation and poor sleep quality (Kruger \& Djerf, 2017; Muflih, Hamzah, \& Purniawan, 2017; Seo, Park, Kim, \& Park, 2016).

How to cite:

E-ISSN:

Published by:
Farjantoky, B., Sunawan, S., \& Mulawarman, M. (2020). The Effects of Cognitive-Behavioral Counseling on Self-esteem and Tendency of Mobile Phone Addiction. Islamic Guidance and Counseling Journal, 3(1). https://doi.org/10.25217/igcj.v3i1.625

2614-1566

Institut Agama Islam Ma'arif NU (IAIMNU) Metro Lampung 
Mobile phone addiction is a tendency or connection to a mobile phone or smartphone due to overuse (Gao et al., 2018; Parasuraman, Sam, Yee, Chuon, \& Ren, 2017). Someone who experiences these problems has almost the same characteristics with the criteria of substance abuse and gambling which are categorized in addictive behavior (Billieux, 2012), which is seen in the Diagnostic and Statistical Manual of Mental Disorders, Fifth Edition (DSM-V) related to the effects of mobile phone users' exclusive problems, namely: improper and compulsive behavior, withdrawal, tolerance, unsuccessful attempts to control, and functional impairment (Association, 2013; Lin, Lin, Yang, \& Kuo, 2017). This explanation confirms that mobile phone users are prone to experiencing personal, social, behavioral, and affective problems in their daily activities or impulse control disorders in individuals (Chóliz, 2010; Kwon, Kim, Cho, \& Yang, 2013; Lin et al., 2017). Therefore this problem is considered important and needs to be investigated.

From these problems, it can be seen that the impact of compulsive mobile phone use is addictive behavior which is very detrimental to the user (Demirci, Orhan, Demirdas, Akpinar, \& Sert, 2014). In accordance with the findings of You, Zhang, Zhang, Xu, \& Chen (2019), it shows that it becomes strong or weakened by the use of mobile phones due to several things such as self-esteem, meaning that when one's self-esteem tends to below, it is likely that the use of a compatible mobile phone will be higher than that of a person who has self-esteem the better one.

Self-esteem is a sense that is found in an individual which is more on a person's worthiness to be considered by others for himself (Rosenberg, Schooler, Schoenbach, \& Rosenberg, 1995). Concerning the tendency to use mobile phone addiction, self-esteem is very influential for changes in behavior in a person. It can be seen that the low self-esteem of mobile phone users will indicate that the tendency of using mobile phone addiction is high. But on the contrary, if a student has a high level of self-esteem, the tendency for using mobile phone addiction is low (Hong, Chiu, \& Huang, 2012; Park \& Lee, 2014). Problems arising from self-esteem originating will also have a negative influence on the use of mobile phones and even have an addictive effect on personal and social life (van Velthoven, Powell, \& Powell, 2018). So that if a teenager has high self-esteem, then he will be able to process his social environment and be able to use a mobile phone following the goals he needs (Dlodlo, 2014).

One of the approaches that can affect self-improvement in his personal and social problems related to self-esteem which impacts addictive relationships that increase mobile addiction is to use health policies implemented by individual counseling services. According to You et al., (2019) research there are differences that occur in agreement related to cognitive assistance that gives effect to adolescents who experience an increase in mobile addiction related to social problems and self-esteem, one of them is self-esteem in a teenager. The cause of problematic self-esteem (low) becomes an important thing that must be corrected can affect the use of mobile addiction that is better and more directed.

Cognitive-behavioral interventions will assist individuals in developing abilities from various angles that occur in individuals (Wilding \& Milne, 2013). According to Young, (2007), the cognitive behavior approach or CBT is a highly representative approach to changing thoughts and adaptive behavior. The CBT approach has a great effect in solving problems related to low self-esteem in students, reducing the presence of depressive symptoms and in someone who has a learning disability that is good through the provision of training; cognitive-behavioral groups as a group (Kolubinski, Frings, Nikčević, Lawrence, \& Spada, 2018; Shaarbaf, Timuri, Sanadgol, \& Gazidari, 2015). In addition, the CBT approach has an effect on internet addicts on mobile phones where CBT with Internet Addicts provides effective results in the improvement of internet addiction symptoms in the form of mobile phones where it can be seen that more than $70 \%$ of internet addicts are able to maintain time 
management and use for recovery (Young, 2007). In line with this research, the cognitivebehavioral approach also helps overcome cognitive, social, and behavioral problems in compulsivity which results in adolescent mobile phone addiction (Kwon et al., 2013).

The above explanation emphasizes that cognitive-behavioral counseling has a high efficacy on self-esteem and mobile phone addiction separately. Because by using the cognitive-behavioral approach, it can provide more effects for low self-esteem by improving mindset and training in behavior (Kolubinski et al., 2018; Shaarbaf et al., 2015). Besides, the cognitive-behavioral approach also provides a change of mindset to improve behavior in users who are addicted to mobile phones (Young, 2007). Based on previous research, there are research limitations where there are no interventions that affect cellular addiction users because this study only looks at the relationship between self-esteem and the tendency of cellular addiction and recommends the need to focus directly on cognitive-behavioral counseling interventions (You et al., 2019). Also, there are not many studies that directly look at the effects of cognitive-behavioral interventions on self-esteem and mobile addiction. Therefore, this study intends to identify the effect of cognitive-behavioral counseling interventions on self-esteem and the tendency of mobile addiction. This finding is expected to prove the identification effect of cognitive counseling on self-esteem and the tendency of mobile phone addiction in students.

\section{METHODS}

Participants who took the pretest are 120 students from all $10^{\text {th }}$ grade (Accounting 1, Accounting 2, Marketing, Animation) of Vocational School 1 Muhammadiyah Semarang. Purposive sampling technique is used to select subjects with low self-esteem students' criteria and a high tendency for mobile phone addiction, so that 12 students are selected. Furthermore, random assignments are applied to subjects that have been collected to determine the group (6 students of the experimental group, 6 students of the control group), the situation is carried out to equalize within each group.

The data collected in this study uses 2 scales that have been previously conducted by researchers for equivalence (equality) scale and back-translation process, then proceed to the validation by experts and test instruments. The scale used in this study is, the Self-esteem scale from the Short Form of Coopersmith Self-esteem Inventory (SF-CSEI) scale is developed by Potard et al. (2015). On this scale consists of 25 items with 2 self-adjustment options and from the test results the instrument is declared valid $\left(r_{x y}: 0.180-0.538\right)$ and value of alpha 0.705. Furthermore, the mobile phone addiction scale from the Smartphone Addiction Inventory (SPAI) scale is developed by Lin et al. (2014). On this scale consists of 9 items with 4 levels of scale and from the test results the instrument is declared valid $\left(\mathrm{r}_{\mathrm{xy}}\right.$ : $0.433-0.713$ ) and an alpha value of 0.928 .

This research is conducted with an experimenter who used a pretest-posttest control group design involving two groups, namely the experimental group and the control group. In the experimental group is the intervention group that is given cognitive-behavioral individual counseling, while the control group is a group (placebo). In this research, there are several steps in implementation. First, giving a pretest to see the level of self-esteem and the tendency of mobile phone addiction to students before giving an intervention. Second, giving intervention to the experimental group in the form of cognitive-behavioral counseling that is done by individual services related to the problem (self-esteem, the tendency of mobile phone addiction), while the control group is only conventionally given individual services (without discussion of the problem). Each meeting is held 6 times with $2 \times 40$ minutes per session. Third, giving a posttest to both groups to find out the results of changes in self-esteem, and the tendency of mobile phone addiction after the intervention is given. 
After the pretest and posttest data are collected and analyzed using the MANCOVA test analysis using SPSS 23 micro software. The MANCOVA test is used to determine the effect and magnitude of cognitive-behavioral counseling on interpersonal sensitivity, self-esteem and mobile phone addiction in design trials.

\section{RESULTS AND DISCUSSION}

The results of the data collected (pretest-posttest) are then tabulated before data analysis is performed. Before being given an intervention the condition of self-esteem of students is at a low level (6 students) and the tendency of mobile phone students is at a high level (6 students). After getting intervention, there are changes in self-esteem and the tendency of mobile phone addiction. In the experimental group self-esteem is at a high level of 6 students and the tendency of mobile phone addiction at a low level was 6 students, while the selfesteem control group is at a moderate level of 5 students, at a low level of 1 student, and a mobile phone tendency addiction at medium level with 6 students. Then, the data is analyzed using the MANCOVA test to prove the results of the effects of cognitive-behavioral counseling on self-esteem and the tendency of mobile phone addiction. This can be seen in Table 1.

\begin{tabular}{|c|c|c|c|c|c|c|c|c|}
\hline \multirow{3}{*}{ Group } & \multicolumn{4}{|c|}{ Self-Esteem } & \multicolumn{4}{|c|}{ Mobile Phone Addiction } \\
\hline & \multicolumn{2}{|c|}{ Pretest } & \multicolumn{2}{|c|}{ Postest } & \multicolumn{2}{|c|}{ Pretest } & \multicolumn{2}{|c|}{ Postest } \\
\hline & $\mathrm{M}$ & $\mathrm{SD}$ & M & $\mathrm{SD}$ & M & $\mathrm{SD}$ & $\mathrm{M}$ & $\mathrm{SD}$ \\
\hline Experiment & 28,16 & 1,72 & 47,33 & 1,21 & 94,33 & 4,50 & 47,16 & 1,72 \\
\hline Control & 29,00 & 0,63 & 33,38 & 1,16 & 86,66 & 2,33 & 74,66 & 2,80 \\
\hline
\end{tabular}

Table 1. Mean and Standard Deviation

Based on Table 1. Mean and Standard Deviation shows that the self-esteem of the experimental group experienced a drastic increase in the average from pretest $(M=28.16$; $\mathrm{SD}=1.72)$ to posttest $(\mathrm{M}=47.33 ; \mathrm{SD}=1.21)$ compared with the control group which increase at pretest $(\mathrm{M}=29.00 ; \mathrm{SD}=0.63)$ and posttest $(\mathrm{M}=33.38 ; \mathrm{SD}=1.16)$. Meanwhile, the mean and standard deviation of the tendency of the mobile phone addiction experimental group decrease dramatically from the pretest $(M=94.33 ; S D=4.50)$ to the posttest $(M=47.16 ; S D=1.72)$ compared to the control group decrease at pretest $(\mathrm{M}=86.66 ; \mathrm{SD}=2.33)$ and posttest $(\mathrm{M}=74.66 ; \mathrm{SD}=2.80)$.

\begin{tabular}{cccc}
\hline Variable & $\mathrm{F}(1.8)$ & $\mathrm{p}$ & $\eta \mathrm{p} 2$ \\
\hline Self-esteem & 265.28 & $<0.001$ & 0.963 \\
Mobile phone addiction & 1115.90 & $<0.001$ & 0.973 \\
\hline
\end{tabular}

Table 2. MANCOVA Test Results

Based on Table 2. MANCOVA above that cognitive-behavioral counseling has the effect that there is Self-esteem $\left(F 1.8=265.28 ; \eta_{\mathrm{p}}{ }^{2}=0.963 ; \mathrm{p}<0.001\right)$, and the tendency of mobile phone addiction $\left(\mathrm{F} 1.8=1115.90 ; \eta_{\mathrm{p}}^{2}=0.973 ; \mathrm{p}<0.001\right)$.

This is in line with the research findings of Kolubinski et al. (2018) that the CBT approach has a large effect in solving problems related to increasing low self-esteem in students, reducing the presence of depressive symptoms and in someone who has a learning disability that is good through the provision of cognitive-behavioral training. Furthermore, Shaarbaf et al. (2015) also explain that cognitive-behavioral counseling improving selfesteem in adolescence. Besides, Young (2007) found that counseling with cognitivebehavioral approaches or CBT effects of exploration on the mind in reducing the use of smartphones that cause addiction in students. Equally, Kim (2013) concludes that the 
cognitive-behavioral approach also helps to overcome cognitive, social, and behavioral problems in compulsivity which results in adolescent mobile phone addiction.

It is seen that cognitive-behavioral counseling affects students who experience problematic self-esteem which impacts the use of mobile phone addiction. Like previous studies where You et al., (2019) recommends more intervention in cognitive-behavioral counseling to give effect to students who experience mobile phone addiction in students due to social and personal problems, one of which is self-esteem. Based on previous research recommendations, where this research proves the effect of cognitive-behavioral counseling on self-esteem and mobile phone addiction.

With cognitive-behavioral counseling has a positive effect on overcoming cell phone abuse and developing skills in healthy internet use (Erden \& Hatun, 2015). It also refers to the purpose of a cognitive-behavioral approach that works based on my behavior and emotions that an individual has which is more about the perception of what he already knows. Thus, this condition will provide learning for students in responding to existing situations and be able to think positively, and be responsible for changing the way of thinking that causes cognitive distortion and addiction behavior that inhibits self-esteem in students and the use of mobile phones that are more appropriate with the aim of benefiting in his life.

Based on the findings of this study, the cognitive-behavioral counseling implications have a high efficacy on self-esteem and the tendency of mobile phone addiction separately. Also, the effect on the identification of self-esteem on the tendency of mobile phone addiction is applied by cognitive-behavioral counseling in individual services.

Besides, what needs to be addressed by the counselor in the implementation of cognitive-behavioral counseling towards self-esteem and mobile phone addiction is the time when sufficient availability will have a better effect as a cognitive modification process of the counselee's behavior in service delivery (Corey, 2013). This will affect self-esteem and the tendency of mobile phones for students in the counseling process.

The findings of this study prove that there is an effect of cognitive-behavioral counseling on self-esteem and the tendency of mobile addiction in students of the Vocational School 1 Muhammadiyah Semarang. However, the findings of this study are still subject to limitations because they are only done in the form of individual services. Thus it is recommended for future researchers to be able to do the same research but in the form of different counseling services and the need for more subjects such as using psychoeducation services or group services.

\section{CONCLUSIONS}

The findings of this study prove that there is an effect of cognitive-behavioral counseling identification intervention on self-esteem and mobile phone addiction. Based on this study, counselors or school guidance counseling teachers can use cognitive-behavioral counseling towards self-esteem and the tendency of mobile phone addiction. Besides, for future researchers to be able to do the same research but in the form of different counseling services and the need for more subjects such as, by using psychoeducation services or group services.

\section{ACKNOWLEDGMENTS}

The author expresses their sincere thanks to Awalya, M.Pd., Kons. for the supervision of research and adaptation of research instruments. Nur Indah Yuniati, S.Pd, M.Si as the head of Vocational School 1 Muhammadiyah Semarang who has given permission to carry out research and Indah Hidayati S. Pd. involved in conducting research. 


\section{AUTHOR CONTRIBUTION STATEMENTS}

BF designs research implementation, data collection, and interventions at the research location. SN and MW provide direction as well as assisting in the preparation of research designs and supervision during the research carried out on site.

\section{REFERENCES}

Association, A. P. (2013). Diagnostic and Statistical Manual of Mental Disorders (DSM-5®). American Psychiatric Pub. Retrieved from Google Scholar

Billieux, J. (2012). Problematic Use of the Mobile Phone: A Literature Review and a Pathways Model. Current Psychiatry Reviews, 8(4), 299-307. https://doi.org/10.2174/157340012803520522

Chen, L., Yan, Z., Tang, W., Yang, F., Xie, X., \& He, J. (2016). Mobile phone addiction levels and negative emotions among Chinese young adults: The mediating role of interpersonal problems. Computers in Human Behavior, 55, 856-866. https://doi.org/10.1016/j.chb.2015.10.030

Chóliz, M. (2010). Mobile Phone Addiction: A Point of Issue. Addiction, 105(2), 373-374. https://doi.org/10.1111/j.1360-0443.2009.02854.x

Corey, G. (2013). Theory and practice of counseling and psychotherapy. Belmont, CA: Cengage Learning. Retrieved from Google Scholar

Demirci, K., Orhan, H., Demirdas, A., Akpinar, A., \& Sert, H. (2014). Validity and Reliability of the Turkish Version of the Smartphone Addiction Scale in a Younger Population. Klinik Psikofarmakoloji Bülteni-Bulletin of Clinical Psychopharmacology, 24(3), 226-234. https://doi.org/10.5455/bcp.20140710040824

Dlodlo, N. (2014). Measuring Selected M-Texting Addiction Indicators with Gender and SelfEsteem. Mediterranean Journal of Social Sciences, 5(23), 489-499. https://doi.org/10.5901/mjss.2014.v5n23p489

Emanuel, R., Bell, R., Cotton, C., Craig, J., Drummond, D., Gibson, S., Williams, A. (2015). The truth about smartphone addiction. College Student Journal, 49(2), 291-299. Retrieved from Google Scholar

Erden, S., \& Hatun, O. (2015). The Use of Cognitive-Behavioral Therapy in Coping with Internet Addiction: A Case Study. Addicta: The Turkish Journal on Addictions, 2(1), 53-83. https://doi.org/10.15805/addicta.2015.2.1.015

Gao, T., Li, J., Zhang, H., Gao, J., Kong, Y., Hu, Y., \& Mei, S. (2018). The influence of alexithymia on mobile phone addiction: The role of depression, anxiety and stress. Journal of Affective Disorders, 225, 761-766. https://doi.org/10.1016/j.jad.2017.08.020

Heriyanto, T. (2018). Indonesia Masuk 5 Besar Negara Pengguna Smartphone. Detik.net. Accessed 18 November 2018. Retrieved November 18, 2019, from Detik.Net website: https://inet.detik.com/telecommunication/d-4551389/pengguna-internet-indonesiadidominasi-milenial.

Hong, F.-Y., Chiu, S.-I., \& Huang, D.-H. (2012). A model of the relationship between psychological characteristics, mobile phone addiction and use of mobile phones by Taiwanese university female students. Computers in Human Behavior, 28(6), 21522159. https://doi.org/10.1016/j.chb.2012.06.020

Indonesia, A. P. J. I. (2018). Responden Survei Nasional Penetrasi Pengguna Internet 2018 [Goverment]. Retrieved November 28, 2019, from Polling Indonesia website: https://apjii.or.id/survei

Kim, H. (2013). Exercise rehabilitation for smartphone addiction. Journal of Exercise Rehabilitation, 9(6), 500-505. https://doi.org/10.12965/jer.130080

Kolubinski, D. C., Frings, D., Nikčević, A. V., Lawrence, J. A., \& Spada, M. M. (2018). A systematic review and meta-analysis of CBT interventions based on the Fennell model 
Farjantoky, B., Sunawan, S., \& Mulawarman, M.

of low self-esteem. Psychiatry Research, 267, 296-305. https://doi.org/10.1016/j.psychres.2018.06.025

Kruger, D. J., \& Djerf, J. M. (2017). Bad vibrations? Cell phone dependency predicts phantom communication experiences. Computers in Human Behavior, 70, 360-364. https://doi.org/10.1016/j.chb.2017.01.017

Kwon, M., Kim, D.-J., Cho, H., \& Yang, S. (2013). The Smartphone Addiction Scale: Development and Validation of a Short Version for Adolescents. PLOS ONE, 8(12), e83558. https://doi.org/10.1371/journal.pone.0083558

Lin, Y.-H., Chang, L.-R., Lee, Y.-H., Tseng, H.-W., Kuo, T. B. J., \& Chen, S.-H. (2014). Development and Validation of the Smartphone Addiction Inventory (SPAI). PLoS ONE, 9(6), e98312. https://doi.org/10.1371/journal.pone.0098312

Lin, Y.-H., Lin, S.-H., Yang, C. C. H., \& Kuo, T. B. J. (2017). Psychopathology of Everyday Life in the 21st Century: Smartphone Addiction. In C. Montag \& M. Reuter (Eds.), Internet Addiction: Neuroscientific Approaches and Therapeutical Implications Including Smartphone Addiction (pp. 339-358). https://doi.org/10.1007/978-3-31946276-9_20

Muflih, M., Hamzah, H., \& Purniawan, W. A. (2017). Penggunaan Smartphone dan Interaksi Sosial pada Remaja di SMA Negeri 1 Kalasan Sleman Yogyakarta. Idea Nursing Journal, 8(1), 12-18. http://www.jurnal.unsyiah.ac.id/INJ/article/view/8698

Parasuraman, S., Sam, A., Yee, S. K., Chuon, B. C., \& Ren, L. (2017). Smartphone usage and increased risk of mobile phone addiction: A concurrent study. International Journal of Pharmaceutical Investigation, 7(3), 125. https://doi.org/10.4103/jphi.JPHI_56_17

Park, N., \& Lee, H. (2014). Nature of Youth Smartphone Addiction in Korea: Diverse Dimensions of Smartphone Use and Individual Traits. Journal of Communication Research, 51(1), 100-132. https://doi.org/10.22174/jcr.2014.51.1.100

Potard, C., Amoura, C., Kubiszewski, V., Le Samedy, M., Moltrecht, B., \& Courtois, R. (2015). Psychometric Properties of the French Version of the Short Form of the Coopersmith Self-Esteem Inventory Among Adolescents and Young Adults. Evaluation \& the Health Professions, 38(2), 265-279. https://doi.org/10.1177/0163278715568990

Rosenberg, M., Schooler, C., Schoenbach, C., \& Rosenberg, F. (1995). Global self-esteem and specific self-esteem: Different concepts, different outcomes. American Sociological Review, 141-156. Retrieved from Google Scholar

Sapacz, M., Rockman, G., \& Clark, J. (2016). Are we addicted to our cell phones?. Computers in Human Behavior, 57, 153-159. https://doi.org/10.1016/j.chb.2015.12.004

Seo, D. G., Park, Y., Kim, M. K., \& Park, J. (2016). Mobile phone dependency and its impacts on adolescents' social and academic behaviors. Computers in Human Behavior, 63, 282-292. https://doi.org/10.1016/j.chb.2016.05.026

Shaarbaf, H. R. A., Timuri, S., Sanadgol, M., \& Gazidari, E. (2015). Assessment of Effectiveness of Cognitive-Behavioral Group Training on Self-Esteem and Achievement Motivation of High School Students. Future of Medical Education Journal, 5(4). https://doi.org/10.22038/fmej.2015.6399

van Velthoven, M. H., Powell, J., \& Powell, G. (2018). Problematic smartphone use: Digital approaches to an emerging public health problem. DIGITAL HEALTH, 4, 205520761875916. https://doi.org/10.1177/2055207618759167

Wilding, C., \& Milne, A. (2013). Cognitive Behavioural Therapy: A Teach Yourself Guide (3rd Edition). Retrieved from Google Scholar

You, Z., Zhang, Y., Zhang, L., Xu, Y., \& Chen, X. (2019). How does self-esteem affect mobile phone addiction? The mediating role of social anxiety and interpersonal sensitivity. Psychiatry Research, 271, 526-531. https://doi.org/10.1016/j.psychres.2018.12.040 
The Effects of Cognitive-Behavioral Counseling on Self-esteem and Tendency of Mobile Phone Addiction

Young, K. S. (2007). Cognitive Behavior Therapy with Internet Addicts: Treatment Outcomes and Implications. CyberPsychology \& Behavior, 10(5), 671-679. https://doi.org/10.1089/cpb.2007.9971

Copyright holder :

(c) Farjantoky, B., Sunawan, S., \& Mulawarman, M. (2020)

First publication right :

(C) Islamic Guidance and Counseling Journal

This article is licensed under:

CC-BY-SA 